\title{
Maciej Witkowski*
}

Wyższa Szkoła Biznesu w Dąbrowie Górniczej

\section{„10 PRAKTYCZNYCH SPOSOBÓW NA INTEGRACJĘ ROMÓW”, CZYLI ANALIZA WSPÓŁCZESNEJ SYTUACJI SPOŁECZNOŚCI ROMSKICH Z PERSPEKTYWY ANTROPOLOGII DARÓW}

\begin{abstract}
W artykule przedstawione zostaną przeprowadzone na przestrzeni ostatnich trzech lat wyniki etnograficznych badań terenowych w osadach romskich w Polsce i ich społecznym otoczeniu. Społeczności romskie w Polsce poddawane są obecnie intensywnym oddziaływaniom ze strony społeczeństwa większościowego, których celem jest społeczno-ekonomiczna integracja. Podobnie jak w klasycznym studium Marcela Maussa tu także mamy do czynienia z oczekiwaną wymianą wartości. Społeczeństwo większościowe składa dar w formie funduszy na „praktyki integracyjne” i jednocześnie liczy, że społeczności romskie na zasadzie wzajemności porzucą te elementy swojego tradycyjnego sposobu życia, które wydają się nie do zaakceptowania w „demokratycznym” i ,zintegrowanym” społeczeństwie. W wymianie darów, w przeciwieństwie do działań w zakresie gospodarki towarowej, zazwyczaj bardziej chodzi o działanie symboliczne niż zaspokajanie „obiektywnych” potrzeb. Wymiana darów jest raczej znakiem wzajemnego uznania, taktyką budowania więzi społecznej. Badania pokazują, że dotychczasowa praktyka integrowania przez dary czasem prowadzi do moralnego poniżenia i pogłębienia marginalnej pozycji Romów.
\end{abstract}

Słowa kluczowe: integracja Romów, inkluzja Romów, wymiana darów, mniejszości etniczne w Polsce, antropologia ekonomiczna

\section{WPROWADZENIE}

Jednym z głównych argumentów za przeprowadzeniem polskiej transformacji systemowej była konieczność zmiany charakteru dominującej racjonalności ekonomicznej. Polskie elity, wzorem rozwiązań zachodnich, przyjęły myślenie neoliberalne, które jak wówczas uznano najlepiej nadawało się do administrowania wprowadzonym kapitalizmem. W niemal każdym z badań socjologicznych poddających refleksji przeobrażenia społeczeństwa polskiego w ciągu ostatnich 20-25 lat podkreśla się, że ekonomiczny wymiar naszego życia stał się ważniejszy, bardziej znaczący i różnicujący. Neoliberalizm ekonomiczny przeobraził nie tylko stosunki między państwem, jednostkami, członkami rodzin, poszczególnymi grupami pracowników, przedsiębiorstwami i rynkami. Instytucjonalizacja neoliberalnych rozwiązań,

* Adres do korespondencji: Maciej Witkowski, Wyższa Szkoła Biznesu w Dąbrowie Górniczej, Katedra Socjologii, ul. Cieplaka 1C, 41-300 Dąbrowa Górnicza, e-mail: maciekw@ae.katowice.pl 
a także dominacja neoliberalnego dyskursu o gospodarowaniu nadały nową jakość relacjom między społeczeństwem większościowym a mniejszościami etnicznymi i narodowymi. Nowe sposoby organizowania procesów produkcji, radzenia sobie w nowej sytuacji ekonomicznej zmieniły także sposób opisywania relacji mniejszość-większość. Jednocześnie nowy sposób gospodarowania stał się nie tylko tłem, ale także obiektywną racjonalnością stosunkowo rzadko poddawaną refleksji.

Analizowano, co dzieje się z mniejszościami, nie zwracając uwagi na neoliberalną kapitalistyczną optykę, przez którą na nie spoglądano (Witkowski, Wódz 2012: 174-181). Proponuję, by czynników mikro- i makroekonomicznych nie ujmować wyłącznie jako symbolicznego tła dla procesów mobilizacji etnicznej i relacji Polaków z grupami etniczno-kulturowymi w państwie, ale postrzegać je także jako kulturowo usankcjonowane źródła moralności (Sedláček 2012: 19). Dalsza część tekstu poświęcona została prowadzonej z takiego punktu widzenia analizie skromnego wycinka tego obszernego zagadnienia. W swoim studium proponuję zastosowanie perspektywy antropologii ekonomicznej (zob. Wilk, Cliggett 2011; Sahlins 1972; Davis 1996), a w szczególności klasycznych rozważań nad procesami dawania i wymiany sformułowanymi przez Marcela Maussa (2001). Zastosowane podejście pozwala zwrócić uwagę na kulturową doniosłość zjawisk wymiany, dystrybucji, konsumpcji, produkcji oraz na lokalny charakter wielu fundamentalnych dla naszej racjonalności pojęć takich jak wartość czy zasada ekwiwalencji. Argumentuję, że oparte na ontologii współczesnego kapitalizmu praktyki „,integrowania Romów” stanowią kluczowy element budowania relacji między Romami a społeczeństwem większościowym III RP.

Wypracowany przez Maussa schemat antropologicznej analizy zjawiska wymiany obiektów materialnych, usług oraz zasadniczo wszelkich aktów dysponowania własną wolą zakładał koncentrację na kilku pojęciach analitycznych, z których najważniejsze są „dar” i „wzajemność”. Sens społecznych rytuałów przekazywania darów zasadzał się w nawiązywaniu relacji społecznych i nadawaniu im znaczenia. Francuski badacz zakładał także istnienie trzech uniwersalnych obowiązków moralnych związanych z sytuacją wymiany darów: dawania, przyjmowania i odwzajemniania. Choć szereg postawionych przez Maussa tez było później mocno krytykowanych (w szczególności koncepcja hau, ducha daru, który był odpowiedzialny za uniwersalną potrzebę odwzajemnienia), nie ulega wątpliwości, że jego rozważania o darze do dziś są głównym punktem odniesienia antropologicznych studiów wymiany (Gudeman 2001). Tezą, która okazała się najbardziej inspirującą dla badań antropologicznych jest przekonanie o ambiwalentnym charakterze aktów przekazywania darów. Jak ujął to Mauss: „Nieodwzajemniony dar wciąż jeszcze poniża tego, kto go przyjął, zwłaszcza wtedy, gdy został on przyjęty bez perspektywy odwzajemnienia. [...] Miłosierdzie jest wciąż jeszcze bolesne, dla tego, kto z niego korzysta, a cały wysiłek naszej moralności zmierza do likwidacji bezwiednie obelżywego patronatu bogatego «jałmużnika»” (2001: 287).

\section{PRAKTYKI INTEGRACYJNE}

Pierwsza część tytułu stanowi parafrazę wypowiedzi jednego z moich informatorów, osoby zaangażowanej w pisanie i zarządzanie projektami pomocowymi „,na rzecz społeczności 
romskich w Polsce". Był on całkowicie przekonany o swoim doświadczeniu w branży, twierdził, że o projektach „dla Romów” wie już niemal wszystko w takim stopniu, że mógłby napisać naukową książkę pod mniej więcej takim tytułem. Jednocześnie analiza dokumentów modelujących i monitorujących strategię integracji zarówno w Polsce, jaki i w UE pokazuje, że ostateczny cel integracji Romów nie został jasno określony (zob. Rostas, Ryder 2012: 192). Także nikt wśród badanych przeze mnie realizatorów tej polityki w Polsce, urzędników i wykonawców projektów, nie jest w stanie wskazać, w jakiej sytuacji moglibyśmy uznać, że „integracja społeczności romskich” dokonała się oraz co miałby ten stan konkretnie oznaczać. Rozmowy z osobami zaangażowanymi w realizację tego rodzaju działań pokazują, że w Polsce obserwujemy zjawisko nazywane przez Elenę Marushiakovą i Vesselina Popova (2005: 445-448) „cygańskim przemysłem” (Gypsy industry). W literaturze naukowej pojawiło się ono w latach 90. dwudziestego wieku wraz z krytyczną refleksją licznych przedstawicieli społeczeństwa większościowego o funkcjonowaniu programów grantodawczych tworzonych przez różnorodne organizacje dobroczynne, rządy, kościoły, a ostatnio przede wszystkim instytucje europejskie w intencji zmiany sytuacji Romów (Gheorghe 2013; Trubeta 2013). Choć zdecydowana większość podmiotów zainteresowanych działalnością w ramach „cygańskiego przemysłu” ma charakter nieromski, liderzy romscy starają się aktywnie konkurować o środki, podkreślając przy okazji, że przy podziale środków Romowie nie powinni być dyskryminowani (Rostas, Ryder 2012: 198) oraz że tylko Romowie znają potrzeby innych Romów ${ }^{1}$

Mamy do czynienia z określonym popytem na usługi podmiotów oferujących umiejętność świadczenia różnych form wsparcia dla Romów zgodnych z wytycznymi europejskich i krajowych dokumentów strategicznych. Należy zaznaczyć, że w takich państwach jak Czechy, Słowacja, Rumunia czy Bułgaria ów specyficzny rynek ma znacznie starsze tradycje i o wiele większą skalę niż w Polsce. Współczesna refleksja nad sposobami funkcjonowania „cygańskiego przemysłu” w latach 90. pokazuje, że gros ówczesnych funduszy na integrację Romów w Europie Wschodniej zasadniczo zostało zmarnowane, a w każdym razie w bardzo niewielkim stopniu przyczyniło się do poprawy sytuacji (Gheorghe 2013; Biro 2013; Trubeta 2013). Także nowe działania i programy realizowane po wstappieniu państw Europy Centralnej do Unii Europejskiej nie zmieniły zasadniczo sytuacji Romów, mimo że ich kłopoty określa się ,jednym z największych wyzwań dla europejskiej idei równości i sprawiedliwości” (Rostas, Ryder 2012: 187). Sevasti Trubeta (2013: 24) zauważa nawet, że dostrzegany przez społeczeństwo większościowe rozdźwięk między alokowanymi w integrację zasobami a mizernymi wynikami w obszarze zmiany sytuacji Romów prowadzi do „odrodzenia się stereotypowego przekonania, że Romowie są rzekomymi nosicielami «niezmiennej esencji» (dzisiaj powiedzielibyśmy: niezmiennej tożsamości), która jest filarem ahistorycznego «uniwersalnego pojęcia» Romów". Podobny sposób rozumowania prowadzi zatem do wniosku, że obecnie podejmowane działania integracyjne de facto mogą pogłębiać marginalizację (zob. Nowicka, Witkowski 2013).

\footnotetext{
Istotną dewizą podkreślaną przez liderów postulujących zwiększenie romskiej podmiotowości przez świadczenie usług ,integracyjnych” jest „nic dla Romów bez Romów”. Jest to nawiązanie do sloganu porozumienia Decade of Roma Inclusion 2005-2015 zawiązanego przez wiele państw Europy Centralnej i Wschodniej i instytucji międzynarodowych takich, jak np. Bank Światowy czy Open Society Institute zaangażowanych w działania na rzecz praw człowieka, których programy inspirują idee dość odległe od tradycyjnych wzorów kultury romskiej.
} 
W Polsce „romski rynek” także rozwija się znakomicie, angażując działaczy organizacji pozarządowych, pracowników samorządowych, urzędników państwowych, liderów romskich i cyganologów. Wszyscy oni dostarczają cennych usług niezbędnych do działań „,integracyjnych". Oczywiście sami Romowie będący przedmiotem działań wspierających także odnoszą różnego rodzaju korzyści. W kategoriach bezpośredniego materialnego zysku ich najbardziej konkretnym wyrazem są inwestycje $\mathrm{w}$ infrastrukturę mieszkaniową, w jednym przypadku wybudowano nawet wielorodzinną kamienicę. Jednak ogromna większość funduszy jest przeznaczana na kursy, wsparcie edukacyjne i różne formy przygotowywania Romów do pełnoprawnego zaangażowania w życie współczesnego demokratycznego społeczeństwa kapitalistycznego.

Obecnie w Polsce dwa główne źródła funduszy na „integrację” Romów to program rządowy, wprowadzany w życie przez Ministerstwo Administracji i Cyfryzacji oraz tzw. „komponent romski” Programu Operacyjnego Kapitał Ludzki (poddziałanie 1.3.1) zarządzany przez Władzę Wdrażającą Projekty Europejskie. Łącznie z obu źródeł na integrowanie Romów wydawanych jest rocznie około 20 milionów PLN. Jeśli założymy, że w Polsce mieszka około 20 tysięcy Romów (szacunki w zależności od zastosowanej metodologii wahają się od 14 do 30 tys.) uzyskamy kwotę około 83 zł na osobę miesięcznie. Oczywiście za te środki u wyspecjalizowanych profesjonalistów (część z nich należy do nowej romskiej elity intelektualnej) kupuje się usługi dla Romów biorących udział w projektach: działania budujące postawy prozatrudnieniowe i proedukacyjne, szkolenia z przygotowywania tzw. „suchych kompozycji” (przeznaczonych na sprzedaż robionych ręcznie ozdób), kursy pierwszej pomocy, szkolenia z praw przysługujących mniejszościom itd. Fundusze z Kapitału Ludzkiego i środki polskiego budżetu stanowią znaczący strumień finansowy stwarzający Romom - prawdopodobnie ograniczoną w czasie - specyficzną niszę ekonomiczno-społeczną. Ta szczególna forma protekcjonizmu ekonomicznego ze strony społeczeństwa większościowego doprowadziła do sytuacji, w której nasze rozumienie ich tożsamości kulturowej, choć nie może być traktowane jak towar na wolnym rynku, osiągnęło status cennego zasobu, możliwego niemal do eksploatacji.

Projekty dla Romów realizowane są w paradygmacie marketingu społecznego. Pojawił się on w latach 70. dwudziestego wieku i szybko stał popularną propozycją wykorzystywania tradycyjnych i sprawdzonych narzędzi marketingowych do realizowania celów społecznie pożądanych, wywoływania zmiany społecznej. Jego popularność stale rośnie zwłaszcza tam, gdzie polityka społeczna opiera się na technokratycznej wizji postępu osiaganego dzięki wierze w rozwój wiedzy. Marketing społeczny dostarcza przede wszystkim aparatury pojęciowej pozwalającej na analizę i bardzo drobiazgowe zarządzanie behawioralnymi i policzalnymi parametrami zmiany. Pozwala także na poczucie zaawansowanej kontroli efektywności zaangażowanych w przedsięwzięcie środków. Jednocześnie jego zastosowanie oznacza konieczność odwoływania się do ustalonych założeń na temat rzeczywistości społecznej, w którą się ingeruje. Jak ujmuje to Katrin Simhandl (2006: 102-107) romskie problemy muszą być „widziane”, „monitorowane” i aksjologicznie znaczące. Dotyczy to zarówno wyjściowego opisu zastanej rzeczywistości, jak i mechanizmów uruchamiania poszczególnych zmian. Zakłada się, że gdy oba rodzaje wiedzy są dostępne, reszta staje się tylko kwestią umiejętnego zarządzania zmianą. Realizując strategię marketingu społecznego, odrzucamy wszelkie 
epistemologiczne wątpliwości dotyczące możliwości dotarcia do rzeczywistości, w której działamy. Epistemologia, a także aksjologia zawarte są już w samym podejściu.

Jak zauważa francuski antropolog Maurice Godelier w odniesieniu do kosmologii ludów głęboko zanurzonych w rzeczywistości współczesnego neoliberalnego kapitalizmu: „Nasze społeczeństwo żyje i prosperuje wyłącznie za cenę permanentnego deficytu solidarności. I nie wyobraża sobie ono nowych więzów solidarności inaczej, jak tylko negocjowanych w formie kontraktów. Jednakże nie wszystko, co buduje więź między ludźmi, co tworzy ich stosunki prywatne i publiczne, społeczne i intymne, co sprawia, iż żyją w społeczeństwie, ale muszą także tworzyć społeczeństwo, by żyć; nie wszystko to jest negocjowalne" (Godelier 2010: 255). Na ile typowy dla społeczeństwa towarowego urynkowiony i zinstytucjonalizowany proces realizowania ,praktyk integracyjnych” ma być pojmowany jako miejsce tworzenia znaczenia zdolnego wygenerować wzajemność lub jakąś inną formę więzi społecznej?

\section{EKONOMIA WYMIANY W RELACJACH ROMOWIE - SPOŁECZEŃSTWO WIĘKSZOŚCIOWE}

Typową narracją współczesnej cyganologii wyjaśniającą genezę współczesnego statusu społeczności romskich można za Adą Engebrigtsen streścić następująco: Cyganie, mimo że niegdyś stygmatyzowani, zawsze zachowywali poczucie własnej godności, znajdując swoje miejsce w wewnętrznej strukturze goszczących ich społeczeństw zarówno w wymiarze ekonomicznym, jak i kulturowym. Dopiero industrializacja zepchnęła ich na marginesy nowoczesnych społeczeństw, gdzie ich kultura powoli się degraduje (Engebrigtsen 2007: 13; Stewart 1997).W dokumentach strategicznych programujących politykę wobec społeczności romskich zarówno na poziomie polskim, jak i europejskim Romowie opisywani są głównie przez pryzmat zaburzonych relacji ekonomicznych ze społeczeństwem większościowym. Popularne w oficjalnym dyskursie integracyjnym pojęcie „marginalizacji społecznej” także ma przede wszystkim wymiar ekonomiczny. Romowie opisywani sąjako społeczność żyjąca poniżej pewnych przyjętych standardów konsumpcji dóbr i usług (także publicznych, takich jak np. edukacja czy opieka zdrowotna) uniemożliwiających im „normalny” sposób zdobywania środków przetrwania. Analiza dokumentów programowych pokazuje, że takie kwestie jak wykluczenie polityczne czy wysoki poziom uprzedzeń i dyskryminacji Romów, nawet w aspekcie rasizmu są zawsze na drugim planie (np. EU Framework for National Roma Integration Strategies up to 2020, 2011, European Commision: COM(2011) 173 final). Sami Romowie, tłumacząc występujące w swojej społeczności zjawiska określane ze strony społeczeństwa większościowego jako negatywne, często powołują się na argument złej sytuacji materialnej lub niewłaściwej organizacji wymiany ekonomicznej, np. na rynku pracy czy pomocy społecznej.

Wiele badań poświęconych tradycyjnej kulturze romskiej i stosunkach Romów z nie-Romami pokazuje, że racje ekonomiczne są z jednej strony główną przyczyną utrzymywania relacji z gadziami (Mirga 1978: 180), a z drugiej źródłem napięć we wzajemnych relacjach. Kulturowo uwarunkowane odmienności w obszarze działań ekonomicznych powodują zarówno negatywne wartościowanie gadziów (Mróz 1986: 139-162; Kowarska 2005: 29-40), jak i kształtowanie uprzedzeń w stosunku do Romów (Bartosz 1978: 131-143), stając się 
jedną z najważniejszych przyczyn obustronnego odczucia dystansu psychologicznego i braku akceptacji (Nowicka 1995; Mróz, 1966: 186). Niektórzy uważają nawet, że tradycyjny system skalań mageripen, podstawa romskiej tożsamości i etnicznego ekskluzywizmu, ma przede wszystkim funkcjonalny charakter ekonomiczny (Leeson 2013). Wzajemne uprzedzenia zasadniczo mają genezę w odmiennych, trudnych do pogodzenia wzorach działań ekonomicznych, co widać chociażby w popularnym stereotypie Cygana złodzieja czy gadzia maniakalnego ciułacza.

Spoglądając na przesiąknięty dyscyplinującą polityczną poprawnością dyskurs o przyczynach współczesnej sytuacji Romów w społeczeństwach europejskich (Trubeta 2013; Vermeersch 2006), trudno uciec od refleksji, że w istocie jest on dość jałowy. Rozstrzyganie kwestii, co jest przyczyną tzw. „romskiej marginalizacji”: kultura Romów, z której nie chcą zrezygnować, czy może wielowiekowa dyskryminacja i rasizm ze strony społeczeństwa większościowego przez wieki znaczące stosunek do Romów, jak zauważa wielu autorów, przypomina dylemat kolistej przyczynowości. Zdrowy rozsądek podpowiada, że formując politykę wsparcia dla społeczności romskich, powinniśmy zlekceważyć kwestie przyczynowości i działać, uwzględniając racje obu stron, co ma swój wyraz w niemal każdym dokumencie dotyczącym polityki wobec społeczności romskich. Ujmując sprawę precyzyjnie: tak nakazuje nie tyle rozsądek, co przyzwoitość.

Trudno odmówić moralnej słuszności tym, którzy twierdzą, że samo rozważanie czy poszukiwanie elementów kultury romskiej odpowiedzialnych za dyskryminację Romów może przyczynić się do szerzenia nienawiści rasowej i etnicznej. Najczęściej zatem gdy pisze się o integracji, jak np. w polskiej strategii, zaznacza się, że „społeczna i gospodarcza integracja Romów jest procesem dwustronnym, wymagającym zmiany nastawienia zarówno większości społeczeństwa, jak i członków społeczności romskiej" (Program Integracji Społecznej Romów na lata 2014-2020: 5). Podobnie Jean Pierre Liégeois (2007), jeden z najbardziej wpływowych ekspertów odpowiedzialnych za formułowanie polityki wobec Romów w Europie, postuluje jako najlepszą metodę zmiany relacji z Romami „wywołanie wewnętrznej dynamiki kulturowej" postępujące wraz ze zdecydowaną walką z wszelkimi formami dyskryminacji Romów. Liczy na to, że dzięki rozwojowi szkolnictwa (dającego pragmatyczne umiejętności egzystencji w społeczeństwie), którego nie należy mylić z edukacją (oznaczająca oddziaływanie związane z przemocą symboliczną) wkrótce będziemy mogli porozumieć się $\mathrm{z}$ mającymi autorytet $\mathrm{w}$ swojej społeczności romskimi elitami zdolnymi przeprowadzić zdecydowaną modernizację kulturową, za którą wezmą przed swoim ludem odpowiedzialność. Jest to wizja, z której wynikają wszystkie działania podejmowane wobec Romów w UE.

W tym kontekście wydany w 2013 roku zbiór artykułów i zapisu dyskusji poświęconej koncepcji integracji Romów pt. From victimhood to citizenship: the path of Roma Integration stanowi rzadki przykład niezwykle otwartej, bardzo subiektywnej, często niezwykle osobistej wymiany stanowisk w tej sprawie. Większość głosów w debacie pochodzi ze strony działaczy romskich z Europy Środkowej (nie było tam nikogo z Polski), pozostałe od specjalnie zaproszonych, zdecydowanie życzliwych dla Romów osób.

Na szczególną uwagę zasługuje głos Nicolae Gheorge'a (zmarł w 2013 roku wkrótce po ukazaniu się publikacji), jednego z najbardziej znanych międzynarodowych działaczy 
romskich, intelektualista, który jak chyba nikt inny w tej społeczności przyczynił się do wypracowania współczesnego europejskiego podejścia do polityki wobec Romów. W kontekście mizernych rezultatów dotychczasowej europejskiej ,praktyki integrowania” stawia on bardzo ważne pytanie o cenę, jaką są w stanie zapłacić Romowie za korzyści płynące z integracji. Chodzi mu o zakres możliwej rezygnacji z dotychczasowego sposobu życia, w szczególności o możliwości przekroczenia kulturowo ukształtowanego stosunku do gadziów wraz z wszelkimi konsekwencjami, jakie wywołałoby to w tradycyjnej strukturze rodziny romskiej, grupowej lojalności, a przede wszystkim w sposobach zdobywania środków na utrzymanie. W skali polityki Unii Europejskiej N. Gheorge (2013) widzi „historyczną szansę” zmiany losu Romów, a jednocześnie obawia się jej zmarnowania. W jego opinii integracja może przybrać różnorodne formy mieszczące się w przedziale między opcją asymilacji z wykorzystaniem obywatelskich praw Romów rozumianych także jako prawa człowieka a opcją romskiego „etnicznego nacjonalizmu” oznaczającego prawne usankcjonowanie kulturowego wzoru życia wyznaczanego przez romanipen, wewnętrzny kodeks moralny. W tej ostatniej ewentualności chodzi jednak o taką wersję romanipen, która byłaby w jakiś sposób możliwa do pogodzenia z prawami człowieka. Rezygnacja z niektórych jego elementów oznaczałaby wspominana wcześniej cenę, jaką można zapłacić za integrację przy jednoczesnym przetrwaniu kultury. W jego interpretacji modernizacja romanipen nie jest tylko kwestią pamięci społecznej, nostalgii czy utraconej kosmologii i poczucia sensu życia, ale przede wszystkim ekonomicznej adaptacji, możliwości zdobywania środków do przetrwania. Odnosząc się do przypadków działania Romów na granicach lub poza granicami prawa społeczeństw większościowych stwierdza: „Ludy nie zawsze są zmuszane, żeby pozostawać w getcie albo na peryferiach, czasami same wybierają żeby tam pozostać. Na marginesie dostępne są pewne możliwości, pewne sposoby działania w cieniu, które nie sąjuż dostępne, kiedy przesuwasz się do centrum albo w stronę świateł reflektorów" (Gheorghe 2013: 59).

Zdaniem Gheorghe'go poszczególne społeczności romskie były w stanie funkcjonować, gdyż miały typową dla biednych i pozbawionych władzy społeczności taktykę przetrwania opartą na podwójnej moralności, która ośmielała do ekonomicznego eksploatowania obcych społeczności: gadziów. Relacje z gadziami wiązały się z traktowaniem ich niemal wyłącznie jako „klientów”, co w połączeniu z często krótkoterminową relacją, jaką nawiązywały niegdyś koczujące grupy, zachęcało do oszustwa. W kulturze romskiej adaptacja i przetrwanie w społecznościach nieromskich opierało się na kształtowaniu psychologicznych umiejętności rozpoznawania i wykorzystywania potrzeb i pragnień. Pogardzano zaś wieloma wartościami ważnymi dla społeczeństwa większościowego, np. wytrwałą pracą nakładczą w społecznościach agrarnych czy planowaniem nieraz odległej przyszłości. W połączeniu z silną solidarnością wewnętrzną i wiarą w specyficzny sposób zachowywania czystości, nieznany gadziom postrzeganym jako istoty z natury brudne, kształtowało to romską tożsamość kulturową i budowało odczuwany dystans psychologiczny i społeczny. Ten swoisty romski etnocentryzm pozwalał na skuteczną adaptację ekonomiczną, a w wielu sytuacjach przeradzał się w przeszłości i przeradza się obecnie w działalność przestępczą. N. Gheorghe podaje tu współczesne przykłady: np. zorganizowane żebractwo, realizację fikcyjnych projektów, wyłudzanie zasiłków z pomocy społecznej, ukrywanie przestępców, przemyt ludzi. W większości 
wersji romskiego kodeksu moralnego romanipen wciąż istnieją zasadnicze różnice między sankcjami przewidzianymi za działanie na szkodę własnej romskiej społeczności oraz społeczności nie-Romów. W pewnych okolicznościach ekonomiczne wykorzystywanie ludzi spoza własnej społeczności staje się usprawiedliwione.

N. Gheorghe jest przekonany, że obecna sytuacja wymaga od Romów podjęcia dużego ryzyka, którym jest rezygnacja z pewnego sposobu postrzegania wzajemnych relacji z gadziami. Zasadniczo zgadza się z nim uczestniczący we wspólnej dyskusji Iulius Rostas, doświadczony działacz organizacji walczących o respektowanie praw człowieka w przypadku Romów, ujmując to następująco: „Ostatecznie mamy do czynienia z projektem politycznym Romów - zupełnie nową tożsamością skonstruowaną przez romskich intelektualistów z zamiarem renegocjowania [sic! M.W.] kontraktu społecznego pomiędzy Romami i nie-Romami. [...] Odnosząc się do procesu budowania relacji pomiędzy Romami i szerszym społeczeństwem, preferuję termin «akomodacja» - w sensie podejmowania negocjacji z innymi - niż «integracja», ponieważ obie strony muszą robić różne ustępstwa” (Rostas 2013: 133).

Jeszcze inny z dyskutantów, nieromskiego pochodzenia, pyta: „Jaka cena powinna być zapłacona przez większość w zamian za wysiłki czynione przez Romów?” (Biro 2013: 175).

Skoro zarówno w oglądzie zewnętrznym, jak i z punktu widzenia zaangażowanych aktorów nawiązywanie relacji między mniejszością romską a społeczeństwem większościowym wskazuje na rolę wymiany i odwołuje się do zakładanej wspólnej normy wzajemności, powyższy stan rzeczy ośmiela, by sprawom przyjrzeć się nieco bliżej w kontekście klasycznej antropologii darów. Podobnie jak w klasycznym studium Maussa tu także mamy do czynienia ze świadczeniem o charakterze całościowym, w którym społeczeństwo większościowe składa dar w formie funduszy na „praktyki integracyjne”, a społeczności romskie zgadzają się porzucić lub zmodyfikować te elementy swojego tradycyjnego sposobu życia, które do tej pory umożliwiały im ekonomiczne przetrwanie na marginesie społeczeństwa większościowego (Mauss 2001). Wyraźnie dostrzegalne jest także, powodujące swoistą niepewność, odroczenie w czasie realizacji zasady wzajemności. Podobnie jak w klasycznym ujęciu francuskiego antropologa w imieniu całych społeczności wymianę darów aranżują uprawnieni przedstawiciele obu grup. Wymiana darów może być także interpretowana jako podstawowa społeczna i symboliczna taktyka budowania relacji pozostających w impasie (Wilk, Cliggett 2011).

Samo odwzajemnienie się za dar nie jest jednak ostatecznym celem podejmowanych działań, obie strony wymianę cenionych wartości traktują raczej jak taktykę ułatwiającą wprowadzanie kolejnych sekwencji wymiany na różnych poziomach interakcji (dokumenty strategiczne, dyskurs urzędniczy, lokalne społeczności uczestniczące w projektach integracyjnych) i w różnych wymiarach egzystencji (pomoc sąsiedzka, zdobywanie środków do życia, zaangażowanie w życie wspólnoty politycznej itp.). Romowie liczą na stopniowe osłabianie i przeciwdziałanie dyskryminacji etnicznej i rasowej, podniesienie poziomu konsumpcji, a przedstawiciele społeczeństwa większościowego na zmniejszanie się przestępczości, odrzucenie przez Romów retoryki ofiar dyskryminacji i wychodzenie Romów z sytuacji stałych klientów pomocy społecznej. Przekazywanie darów, a następnie oczekiwanie na rewanż drugiej strony pozwala ocenić jej intencje. Sytuacje wzajemności mogą być traktowane jako dowody na akceptację wspólnych wartości. 


\section{KONCEPCJA BADAWCZA}

Odwołując się do materiału zgromadzonego w trakcie badań terenowych w lokalnym środowisku romskim, jego bezpośrednim otoczeniu społecznym, a także wywiadów przeprowadzonych z organizatorami projektów romskich, postaram się rozważyć ,,praktyki integracyjne” traktowane jako relacja wymienna oraz pokazać, jak osoby w nią zaangażowane interpretują sytuację. W kontekście zaangażowania w „praktyki integracyjne” przedstawicieli społeczeństwa większościowego pojawia się pytanie o motywacje związane z ofiarowywaniem „integracyjnego” wsparcia i innych „darów” dla społeczności romskiej. „Praktyki integracyjne" mają w chwili obecnej charakter ,profesjonalnych” oddziaływań, realizują je organizacje pozarządowe i firmy, kierując się krótkoterminową kalkulacją ekonomiczną. Przede wszystkim aby sprzedać swoje usługi w postaci przekazywania darów Romom, muszą konkurować z innymi chętnymi do ich realizacji.

Prezentowane w poniższym rozdziale empirycznym materiały zostały zgromadzone w trakcie badań terenowych poświęconych ,praktykom integrowania” Romów, czyli złożonym społecznym działaniom, których oficjalnie deklarowanym celem jest „integracja społeczności romskich ze społeczeństwem większościowym” i które organizowane są zgodnie z państwowymi założeniami polityki w tym zakresie. Przyjąłem, że subiektywne znaczenie działań określanych jako ,integracyjne” jest różne dla poszczególnych aktorów mających różnorodne intencje, interesy i wyobrażenia na temat racjonalności tego rodzaju aktywności. Badania dotyczyły Romów - tych, którzy stali się uczestnikami programów i tych mieszkańców osiedli romskich, którzy tylko je obserwowali, liderów romskich, urzędników państwowych, przedstawicieli organizacji ubiegających się o granty, osób pracujących z Romami w charakterze tzw. trenerów, przedstawicieli samorządu i osób spoza romskich społeczności, które pozostają w sąsiedzkich relacjach z integrowanymi Romami. Głównym przedmiotem mojego zainteresowania jest sytuacja, która wytworzyła się kilka lat po wstąpieniu Polski do UE. W latach 2011-2013, kiedy prowadziłem badania, wiele z praktyk integracyjnych okrzepło, stało się względnie trwałym, wyraźnie odzwierciedlonym w świadomości osób badanych elementem społecznych relacji z Romami, pojawiły się także widoczne konsekwencje tego rodzaju działań (zob. Nowicka, Witkowski 2013).

Większość kluczowych pojęć opisujących politykę stosowaną wobec Romów umieszczam w cudzysłowie ${ }^{2}$. Moim celem jest wyłącznie głębsze zrozumienie zachodzących zjawisk przez spojrzenie na rzeczywistość społeczną z różnych perspektyw, a nie krytyka działań jakichkolwiek podmiotów czy deprecjonowanie „działań integracyjnych”3. Umieszczenie niektórych pojęć w cudzysłowie jest wyłącznie konsekwencją podejścia metodologicznego. W rzeczywistości nie badam zjawiska integracji w rozumieniu socjologicznym jako takiego, a jedynie to, co kontekście nazywane jest „integrowaniem Romów”. „Integracja” jest dla

\footnotetext{
2 Fenomenem i pewnego rodzaju pytaniem badawczym staje się kwestia, dlaczego takie pojęcia jak np. „,integracja Romów”, „marginalizacja” czy „partycypacja” są powszechnie rozumiane i pozwalają organizować ustrukturyzowane działania.

3 Nadmienię tylko, że trudności w ogarnięciu kognitywnego schematu działania lub czynności, które choć niejasne nierzadko znakomicie organizują działania społeczne, nie są same w sobie czymś wyjątkowym (np. kwestia społeczeństwa obywatelskiego, fenomen solidarności, komunizm itp.).
} 
mnie kluczową figurą retoryczną organizującą dyskurs społeczeństwa większościowego o kształtowaniu relacji ze społecznościami romskimi.

Istotę zastosowanej koncepcji badawczej można przedstawić, odwołując się do etnografii wielu miejsc Georga E. Marcusa (1995), który skonceptualizował panujące w latach 80. XX wieku tendencje prowadzenia badań terenowych. W jego interpretacji etnografia wielu miejsc polega na refleksyjnej analizie zależności między badaną społecznością a szerszym systemem czy też systemami (Holmes, Marcus 2009: 653). Rozumienie antropologiczne wyłania się z analizy różnorodnych sposobów reprezentacji lokalnej rzeczywistości, splatających się w „tubylczym” sposobie życia i myśleniu. Zależności między poszczególnymi reprezentacjami stają się elementem interpretacji. Badanie prowadzone w lokalnej społeczności obejmuje zatem analizę ,polityk wiedzy”, zewnętrznych uprzywilejowanych sposobów objaśniania świata, które u „tubylców” pojawiają się na skutek relacji ze światem zewnętrznym. Zainteresowanie wielością racjonalności, których lokalne tropy odnajduje badacz, stawiają go wobec obowiązku gotowości podążania w nowe miejsca. „Kulturowe wzory myślenia, w antropologii tak bardzo niegdyś poszukiwane, są zawsze wytwarzane w wielu miejscach, a każda antropologiczna próba ich poznania pokazuje, że przynajmniej częściowo konstytuują się one wewnątrz którejś części tzw. systemu (np. nowoczesnych instytucji medialnych, rynków, państw, przemysłów, uniwersytetów - światów elit, ekspertów i kasy średniej)" (Marcus 1995: 97).

Miejscem znakomicie nadającym się do zastosowania tego podejścia jest współczesna Unia Europejska. Postępujący proces europeizacji oznacza coraz bardziej intensywne i powikłane zależności między bardzo rozbudowaną i wciąż mocno scentralizowaną strukturą decyzyjną a życiem codziennym ludzi. Wielopoziomowa struktura tzw. governance i podejmowane próby wypełnienia czymś tzw. „deficytu demokracji”, czyli wysiłki, by nadać europejskiej demokracji nieco bardziej oddolny charakter, pozwalają poszukiwać ścieżek współzależności między różnymi poziomami tworzenia znaczenia przypisywanego rzeczywistości społecznej.

Gromadzenie danych etnograficznych rozpoczęło się od badania nieromskiego otoczenia społecznego w kilku karpackich wioskach. Zakres prowadzonych badań stopniowo rozszerzał się na urzędników, pedagogów i przedstawicieli władzy samorządowej, liderów romskich z innych miejscowości, trenerów i organizatorów szkoleń „integracyjnych” dla Romów, urzędników szczebla centralnego. Konsekwentnie plan badań uzupełniono o obserwację uczestniczącą spotkań konsultacyjnych organizowanych przez władze państwowe dla mniejszości romskiej w ramach rozwijania dialogu społecznego, obserwację uczestniczącą prowadzoną w trakcie romskich konferencji międzynarodowych, analizę dokumentów strategicznych z poziomu krajowego i europejskiego. Proponowane wnioski zostały sformułowane na podstawie zróżnicowanego materiału badawczego, zgromadzonego przy użyciu odmiennych metod. W latach 2011-2013 przeprowadzono:

- 25 pogłębionych wywiadów z mieszkańcami, urzędnikami i nauczycielami w okolicach romskich osad i dzielnic;

- etnograficzną obserwację uczestniczącą w dwóch osadach Bergitka Roma polegającą na uczestnictwie w życiu codziennym i wspólnych rozmowach grupowych lub indywidualnych;

- 10 pogłębionych wywiadów z osobami realizującymi projekty „integracyjne” dla Romów; 
- cztery pogłębione wywiady z romskimi liderami;

- trzy pogłębione wywiady z urzędnikami rządowymi odpowiedzialnymi za ,integrację Romów";

- obserwację uczestnicząca dwóch międzynarodowych konferencji romskich, w których brali udział przedstawiciele Romów z Polski;

- analizę zawartości kluczowych dokumentów programujących i opisujących bieżące postępy w integrowani społeczności romskich na poziomie polskim i europejskim.

\section{ANALIZA WYNIKÓW}

\section{DARY I DARY ZA DAR}

Dla piszących i realizujących projekty dla Romów profesjonalistów ich realizacja sprowadza się do przyjmowania retoryki marketingu społecznego. W tej perspektywie, zwłaszcza w odniesieniu do przedsięwzięć finansowanych z funduszy europejskich, finansowane działania powinny przede wszystkim przynosić konkretne „produkty” w postaci: liczby Romów, którzy podejmą pracę, nabędą potwierdzone certyfikatem kwalifikacje zawodowe, liczby kobiet, które zmienią swoje postawy na „prozatrudnieniowe”, liczby osób, które przeszły podstawowe badania lekarskie, liczby dzieci, które uczestniczyły w kursach komputerowych itp. Umiejętne dopasowanie się do specyficznych gatunkowych wymagań dyskursu formularzy aplikacyjnych jest warunkiem wstępnym uzyskania funduszy, dopiero potem próbuje się dopasować zakontraktowane rozwiązania do warunków, w jakich przebiega życie w romskiej osadzie. Warto wspomnieć, że dla wielu z profesjonalistów doświadczenia z Romami zdobywane przy okazji realizacji projektów stają się jednym z najciekawszych doświadczeń w życiu, dla niektórych jednym z najbardziej traumatycznych.

Oczywiście w kontekście przepisów regulujących udzielanie grantów Romowie jako ostateczni konsumenci sfinansowanego przez społeczeństwo większościowe daru przystępują do niego na zasadach dobrowolności. Oznacza to, że Romowie powinni być zachęcani i „motywowani” do udziału w działaniach „,integracyjnych”. Według logiki finansowania ,praktyk integracyjnych" ich zgłoszenie się do projektu można interpretować jako przyjęcie daru.

Jednak organizacje wygrywające konkursy na projekty dla Romów permanentnie zmagają się z podstawowym problemem braku wystarczającej liczby chętnych Romów do realizacji programu.

Mówię im o szkoleniach, co one mówią? Panie [tu imię], ale ile pan płaci? Ja mówię, no jak to, my wam wszystko organizujemy za darmo. Szkolenie za darmo, przejazdy, żywienie, materiały... No tak, ale dobra, ale ile my dostaniemy? Ja mówię, to jeszcze nie praca, wy na razie idziecie na szkolenie, za które nie zapłacicie ani złotówki, będziecie mieć zawód. Panie [tu imię], to my to w tym momencie mamy gdzieś, bo nam w opiece płacą... (wyw. 6).

Dość powszechnym doświadczeniem organizatorów szkoleń są swoiste negocjacje, w których samo przyjęcie daru, staje się darem dla strony podejmującej próby darowania, w dodatku rodzącym poczucie wzajemności: zamiast oczekiwać rewanżu, sami są do niego 
zobligowani. Oczywiście taka sytuacja jest możliwa tylko w warunkach, gdy sam realizator „praktyk integracyjnych” ma powody, by cenić tego rodzaju odwróconą relację przekazywania cenionych wartości.

Dla organizacji szkoleniowych posiadanie dostępu do grupy Romów gotowych uczestniczyć w projekcie (i umiejętność przetrzymania ich do końca) samo w sobie stało się kluczowym zasobem pozwalającym uczestniczyć w ,integracji”. W konsekwencji liderzy romscy, szybko orientując się w sytuacji, starają się poszerzać swoje wpływy w lokalnych społecznościach, bo możliwość nakłonienia (wynikająca z tradycyjnej struktury społecznej Romów i więzów pokrewieństwa), ,swoich” Romów do udziału w projekcie gwarantuje im pewne wynagrodzenie od wykonawcy projektu, co w opinii wielu realizatorów programów oceniane jest negatywnie, w kategoriach ,integracyjnej patologii” (sformułowanie użyte przez jedną z osób realizujących projekty dla Romów). Jednakże nieromscy realizatorzy projektów także zawłaszczają Romów. Na spotkaniach organizowanych przez administrację rządową dla potencjalnych realizatorów grantów z tzw. ,priorytetu romskiego” powszechne jest posługiwanie się sformułowaniem ,nasi Romowie”. Nie chodzi tu o podkreślenie ponadetnicznej więzi czy wspólnej identyfikacji wyższego rzędu, ale raczej o czytelny sygnał dla konkurentów, by Romów do swojego projektu poszukali gdzie indziej. Kontakty w środowisku romskim są też traktowane jak podstawowa kwalifikacja do organizowania projektu. Wiele wypowiedzi sugeruje rodzenie się zindywidualizowanych więzi międzyludzkich, których podłożem jest z jednej strony organizacja, a z drugiej uczestnictwo w projekcie, który staje się przestrzenią wymiany darów i budowany jest na szacunku dla relacji wzajemności:

Często jest tak, że nie ma dostępu do Romów w taki bezpośredni sposób, tylko ja już teraz przez lata doświadczeń mam to, że oni sami do mnie dzwonią, też nie jestem skazany tylko na to, że mi liderzy wskazują (wyw. 2).

Rozmowa jednego z lokalnych liderów romskich (wyw. 4) aspirującego do roli „opiekuna” kilku lokalnych społeczności (jego zaangażowanie w ostatnich latach z pewnym zaskoczeniem relacjonowali także przedstawiciele samorządu) z dwoma etnografami oscylowała, głównie z jego inicjatywy w kierunku możliwości realizacji „projektów”, w których byłby koordynatorem, co w jego rozumieniu oznaczało zagwarantowanie odpowiedniej liczby uczestników projektu w zamian za odpowiednie wynagrodzenie. Świadomość wartości, którą dla realizatorów projektów przedstawia możliwość dysponowania losem innych, wzmacnia pozycję romskich liderów korzystających z tradycyjnych struktur rodowych czy hierarchii autorytetów. Podejmują oni politykę gospodarowania dostępnymi im zasobami. Rozwijana w projektach idea romskiej partycypacji i uwzględniania „romskich potrzeb” w tym kontekście nabiera nowego znaczenia:

Taka dewiza, na którą Romowie są bardzo uczuleni, to: „nic dla Romów bez Romów”. Pojawiają się sytuacje takie, że ktoś im coś napisze, czyli zbierze się grupa, powiedzmy w cudzysłowie naukowców, która w tym momencie stwierdzi, że ona najlepiej wie, co im zrobić, żeby było dobrze i potem się okazuje, że są nagle zbulwersowani, że czegoś nie ma. Taki przykład był gdzieś tam w urzędzie pracy, może też sobie daruję miejscowość, np. napisały dwie panie projekt i nagle do lidera: no to słuchaj, no, bo my tu mamy projekt dawaj ludzi. Lider powiedział, że nie daje ludzi, bo on już z kim innym prowadzi rozmowy i w tym momencie ci ludzie znaleźli się u nas (wyw. 2). 
W trakcie praktyk ,integracyjnych” między organizatorami szkoleń (którymi często są instytucje samorządowe) a szkolonymi społecznościami romskimi na bazie wymiany wartości budowane są więzi oparte na zaufaniu. Oczywiście Romowie otrzymanej wartości w postaci kursów, w założeniu rozwijających ich „kapitał społeczny”, nie traktują jako cennego dobra, które rodzi obowiązek odwzajemnienia, mimo że organizatorzy projektów usilnie do tego dążą. Jedna $\mathrm{z}$ romskich kobiet tak przedstawia sens własnego uczestnictwa w projekcie:

Ja już przykładowo mam ten kurs [pierwszej pomocy] i ja już mogę pomagać ludziom. Jadę gdzieś, stanie się coś czy obojętnie czy to babcia, czy to dziadek... i ja po prostu umiem ratować tych ludzi. [...] Ja już muszę pomóc. To wtedy jest oferta o pracę. Idę do zatrudnienia, daję ten papier i po prostu poszukuję jakąs pracę. Tak właśnie moja siostra dostała tą pracę w szpitalu. I wtedy jest jako pierwsza pomoc [w rzeczywistości jest tam sprzątaczką - M.W.]. I ona już po prostu pomaga tym ludziom, co są chorzy (wyw. 11).

Zgodnie z zasadami finansowania projektów Romom oficjalnie nie można przekazywać żadnych korzyści materialnych. By ich zachęcić do udziału w projekcie, organizatorzy starają się przekazywać im jakieś wygospodarowane środki w postaci tzw. „,cateringu”, wynagrodzenia dla osoby trzeciej (najczęściej kogoś z rodziny), która opiekuje się dzieckiem kursanta podczas szkolenia, lub po prostu nieoficjalnie dzielą się własnym wynagrodzeniem. Aby ustalić naturę przekazywanych ,poza projektem” wartości, np. czy zakup pralki dla romskiej rodziny przez realizatora projektu jest darem wstępnym, czy darem za dar, starałem się poznać interpretacje tej sytuacji dokonane przez obie strony. O ile nie-Romowie prowadzący projekty, z jednej strony zarabiający na ich realizacji, z drugiej wydający swoje ,prywatne” środki na tego rodzaju zakupy, skłonni byli postrzegać je jako prezenty dla przyjaciół i odruch serca, o tyle Romowie przedstawiali je jako wynik uczestnictwa w projekcie, podkreślając przy tym osobistą sympatię dla darczyńców w sposób wskazujący, że doceniają odwzajemnienie. Te pożądane wartości, które w trakcie praktyk integracyjnych wymieniane są poza oficjalnym trybem realizacji projektu, mogą stanowić jedyną formę rzeczywistego daru budującego społeczną integrację. W tej wymianie zasadą jest, że inicjujący dar stanowi ,gotowość Romów do uczestniczenia w projekcie". Niedocenienie jego znaczenia jest poważnym uchybieniem, o czym można się przekonać także z wypowiedzi organizatorów projektu:

Jeżeli chodzi o tych samych Romów, to już mówię z perspektywy lat, jak sobie pomyślę i to nastawienie na początku, takie bardzo roszczeniowe, [...] do tego stopnia, że jeżeli faktycznie ten catering, ten poczęstunek jest w hotelach trzygwiazdkowych, powiedzmy gdzieś tam w lepszym w danym mieście i on [romski uczestnik projektu - M.W.] nagle narzeka, że dostał wodę z kostką, ale nie ma cytryny. [...] Potrafi o to zrobić taką karczemną awanturę, że po prostu robi się niemiło (wyw. 6).

\section{SPOŁECZNE KONSEKWENCJE WYMIANY}

Realizatorzy „projektów integracyjnych” dla Romów starają się pogodzić zapisany w strategii postulat „działania na rzecz powrotu Romów na rynek pracy” z kulturą i romskimi warunkami życia. 
Zasadniczo podążają w dwóch kierunkach:

- minimalistycznej ingerencji w tradycję (,żeby uczyły się robić takie rzeczy, które mogą robić w domach, typu suche kompozycje, bukieciarstwo, te decoupage, to, co się nalepia na tych skrzyneczkach, obrazki, to się zamalowuje, to jest takie jak stare... robienie biżuterii (kolczyków) to są takie rzeczy, że to można robić w domu. Oprócz tego pasków ze skóry, na zasadzie, że tam się skórę, wycina się paski i to można sprzedawać” (wyw. 3)).

- maksymalnej ingerencji, zasypywania różnicy między Romami i nie-Romami, co najczęściej przybiera postać „wyrywania ze społeczności” („To jest tak, że my na pierwszym etapie, wiadomo, proponujemy, a nawet nie tyle proponujemy szkolenia, po prostu rozmawiamy z tymi ludźmi, jak wygląda cały ten projekt, ten proces. Staramy się ich namówić do udziału w tym i my jakby mamy zdecydować, które z tych osób są w stanie ten proces przejść, bo wiadomo, że jest pełno osób, które są chętne, tylko rezygnują np. po dwóch dniach szkolenia" (wyw. 2)).

Interesujący jest zwłaszcza przypadek drugi, rzadszy, ale znacznie trudniejszy w realizacji i o potencjalnie znacznie poważniejszych konsekwencjach społecznych. Poniżej przedstawiam ten szczególnie interesujący przykład praktyk integracyjnych na podstawie wywiadu przeprowadzonego $\mathrm{z}$ jedną osobą pracującą $\mathrm{w}$ tamtym czasie dla firmy szkoleniowej zajmującej się integracją Romów na dużą skalę. Pracownicy zatrudniani przez organizacje zaangażowane w ,praktyki integracyjne” tego rodzaju mają zazwyczaj bogatsze doświadczenia $\mathrm{w}$ pracy w środowiskach romskich niż trenerzy spotykający się z Romami tylko w salach szkoleniowych. W ich przypadku wymiana darów staje się także bardziej intensywna. Jaki charakter ma zatem więź łącząca organizatorów intensywnych ,praktyk integracyjnych" z Romami?

Przede wszystkim dla osób bezpośrednio zaangażowanych w pracę w osadach romskich działania integracyjne wiążą się z lawirowaniem między wymiarem ludzkim - „rzeczywistymi potrzebami Romów” i techniczno-finansowym - performatywnym językiem projektu i zarządzania nim:

Są dwie strony: ludzie zaangażowani społecznie i ludzie, którzy chcą pewne wskaźniki osiagnąć, i cele związane z projektem, no niestety projekty unijne są o tyle trudne do zrealizowania w tej społeczności, są mało elastyczne. Zawsze jest tak, że są pewne kwoty, terminy itd. To wymaga od pracowników bardzo dużej elastyczności i zmieniania pewnych rzeczy gdzieś w trakcie [...] Biorąc pod uwagę to, że to jest projekt unijny, no to, jeżeli ktoś rezygnuje po dwóch dniach szkolenia, to pieniądze $\mathrm{z}$ tego szkolenia - tutaj są dwie strony $-\mathrm{z}$ jednej strony ludzie, $\mathrm{z}$ drugiej strony pieniądze..., no, przepadaja. My musimy na tyle mocno tych ludzi poznać, żeby zdecydować, kto do tego projektu się nadaje i rzeczywiście jest w stanie przejść przez tą ścieżkę (wyw. 2).

Powyższy cytat pochodzi z wywiadu z młodą, ale posiadającą już kilkuletnie doświadczenie w realizacji „praktyk integracyjnych” wśród Romów, mocno zaangażowaną emocjonalnie w działalność projektową osobą. Jej rola polega na wybieraniu ze środowiska romskiego osób nadających się do rekrutacji w projekcie. By skutecznie wykonywać to zadanie, musi najpierw poznać środowisko Romów mieszkających w osadzie, w trakcie szkoleń służyć 
pomocą i pilnować, by osoby zaangażowane w projekt ukończyły go pomyślnie. W praktyce, rekrutując osoby z romskiej osady w jednej z karpackich wiosek, nawiązuje z nimi bliski kontakt, np. mieszkając $w$ ich domach $\mathrm{w}$ trakcie kilkudniowych pobytów, poznając bliższą i dalszą rodzinę, przyjeżdżając na ważne uroczystości. Oczywiście uczestniczy też w wyjazdach szkoleniowych i treningach, a przede wszystkim wymienia dużą liczbę świadczeń, przysług i prezentów. O swojej motywacji do tego rodzaju pracy opowiada:

Nie interesowała mnie praca nie w biurze, ale praca rzeczywiście z tymi ludźmi. To jest zupełnie nowe stanowisko, stworzone trochę przez nas. Polega na tym, że my z ramienia tego projektu idziemy do tych ludzi i obserwujemy ich postępy, ale także staramy się docierać do nich na zasadzie takiej jakby przyjaźni. Wiadomo, że z biura można zadzwonić, pewne rzeczy ustalić, natomiast ci ludzie nie czuja, że mają opiekuna. To jest taki opiekun, który po prostu na każdym etapie..., zawsze można do niego zadzwonić, przyjeżdża raz na jakiś czas do tej ekipy ludzi, którymi się zajmuje. Pracuje tam z tym romskim asystentem środowiskowym, który go informuje o problemach... (wyw. 3).

W trakcie kilkunastu ostatnich lat nie słyszałem o żadnym innym nie-Romie, który byłby z mieszkańcami romskiej osady w tak bliskim kontakcie. Szczególnie charakterystyczny jest język wykorzystywany przez nią do opisu swych doświadczeń z Romami, pokazujący na jakiej płaszczyźnie nawiązywana jest relacja. W ,profesjonalnym”, narzuconym przez pełnioną w społeczności rolę dyskursie nie występują także tradycyjne stereotypy, wciąż widoczne u mieszkających w pobliżu romskiej osady mieszkańców wsi:

W momencie, kiedy ktoś rezygnuje, jest niezmotywowany, no to jeździmy i rozmawiamy z ludźmi o tych problemach itd. [...] Mamy mieć 190, które przejdą ścieżkę aktywizacji zawodowej. No i jeżeli mamy w tym momencie 138, według mnie jest to zbyt duża grupa ludzi do kontrolowania (wyw. 2).

To, co w jej wypowiedzi nazywane jest brakiem motywacji, w powszechnej opinii nieromskich tubylców określa się po prostu lenistwem. Problem traktowany w kategoriach braku zmotywowania staje się wyłącznie kwestią techniczna, możliwą do przezwyciężenia w wyniku profesjonalnego oddziaływania i kontroli.

Porzucając dość oczywiste ramy stosowanej przez nią metafory sprowadzającej Romów do zasobów ludzkich (zapewne wynika ona z charakteru jej pracy w projekcie i wcześniejszego doświadczenia zawodowego), można odnieść wrażenie, że osoba realizująca projekt, poza całą profesjonalizacją własnej obecności w osadzie, nawiązuje pewien rodzaj przyjaźni ze społecznością, w której działa. Proces szkolenia zawodowego oznacza dla niej poznanie i zrozumienie potrzeb Romów. Wiele jej wypowiedzi wskazuje na pewną zażyłość, zaufanie i zaangażowanie emocjonalne pojawiające się w jej relacjach z mieszkańcami osady. Pojawia się także przekonanie o możliwości empatii:

Z takimi sytuacjami spotkałam się nie tylko, jeżeli chodzi o pracę. Tak samo, jeżeli chodzi o pracę, tak samo np. wchodząc do restauracji, kiedy mnie i te osoby wyprosili, prawda... Także ciężko powiedzieć, jak się poczułam. Bardziej zwróciłam uwagę na to, jak oni się czują. Zetknęłam się też z takimi sytuacjami, kiedy zaprosiłam takich moich przyjaciół [z karpackiej wioski do dużego miasta - M.W.] [...]. Oni się mnie zapytali wprost, czy ja nie będę się wstydziła ich zaprosić. 
Wtedy sobie pomyślałam, co człowiek musi myśleć, żeby mieć takie zdanie na swój temat. Sam sobie zdaje sprawę, że może być wstyd, że on się gdzieś pojawił. Ciężko powiedzieć, co ja..., ja nie umiem sobie wyobrazić, żebym sama mogła myśleć tak o sobie (wyw. 2).

Jednak dystans psychologiczny wydaje się wciąż duży, a zaufanie ograniczone. Rekruterka stwierdza, że na rekomendację, w której osobiście poręcza pracodawcy za Roma, to za mało:

Staramy się, żeby były rekomendacje dla tych osób, ale z drugiej strony, my tych osób też nie znamy na tyle, żeby móc za nie ręczyć, prawda? Dlatego tutaj zawsze będzie problem. Tego się nie da rozwiązać w ten sposób, że my pracodawcę zmusimy, żeby kogoś zatrudnił, bo my np. jesteśmy pewni, że ta osoba jest w porządku. To nie dotyczy tylko Romów, to, według mnie, dotyczy każdego. Nie możemy za nich zaręczyć, że będą dobrymi pracownikami (wyw. 2).

Intensyfikacja „działań integracyjnych”, w trakcie których dochodzi do wielu sekwencji wymiany darów, a także przestrzennie bliski kontakt z Romami nie oznaczają, że bariera obcości jest przekraczana. Osoba organizująca treningi romskie zaznacza, że w swoim środowisku, we własnym mieście nie chciałaby pracować z Romami, bo musi dbać o swoją prywatność. Dodaje przy tym, że nie ma żadnego znaczenia, że chodzi tu o Romów:

Tak, ale ja tutaj akurat nie pracuję z tego powodu, że tutaj mieszkam. To jest tak, że ja moge spotkać bardzo ciekawych i fajnych ludzi, a mogę spotkać też ludzi nie... nie chodzi mi o to, czy to są Romowie. Gdybym miała pracować z grupą ludzi długotrwale bezrobotnych, którzy mają jakieś tam oczekiwania i wymagania, no to zakładam, że jakaś część z nich, nawet mała grupa, byłaby codziennie pod moim domem. A też muszę dbać o swoją prywatność, biorąc pod uwagę, że pracuję, do dwudziestej drugiej odbieram i w czymś pomagam... (wyw. 2).

W istocie, formułując bardziej ogólny wniosek na podstawie wyjątkowego, powyżej opisanego przypadku, można stwierdzić, że głębokie zaangażowanie w ,praktyki integracyjne", połączone z intensywną wymianą wzajemnych świadczeń, jest przez przedstawicieli społeczeństwa większościowego postrzegane jako profesjonalne oddziaływanie, w którym zaufanie ma bardzo ograniczony zakres, odczuwany dystans wciąż pozostaje głęboki. Przyjaźń z Romami, choć w realizacji projektu bardzo się przydaje, jest relacją tymczasową o instrumentalnym charakterze:

Ja uczestniczę w tym nie wtedy, kiedy mówimy o problemach romskich, tylko w zabawach stricte, żeby oni mieli takie poczucie, to też jest dla nas ważne, że ja jestem z nimi, częścią ich społeczności, a nie osobą, która gdzieś tam im coś rozkazuje albo o czymś im opowiada (wyw. 2).

\section{„PRAKTYKI INTEGRACYJNE” W PERSPEKTYWIE NIEROMSKICH SPOŁECZNOŚCI LOKALNYCH}

Osoby mieszkające w bezpośrednim sąsiedztwie romskich osad i dzielnic dostrzegają, że w ostatnich latach pojawiło się wiele tzw. „projektów” dla Romów. W powszechnej opinii wsparcie dla Romów nie jest wystarczająco koordynowane: niektórych rzeczy otrzymują zbyt dużo (np. kilka kompletów podręczników szkolnych, które są następnie sprzedawane wśród miejscowych za niewspółmiernie małe pieniądze): 
Jeżeli uczniowie inni widzą, że ci są traktowani inaczej, to dlatego mówię, że ta pomoc czasem szkodzi, a nie pomaga, bo nie dość, że nie chodzi, to jeszcze wszystko dostaje, nie? No to przychodzi mi mama, czy dziecko, ona faktycznie ma sytuację bardzo trudną i nie dostanie nic, natomiast no... tak też jest. Na tym polu się tutaj, no takie pretensje różne słyszy (wyw. 13).

Wśród mieszkańców wsi wywołuje to oburzenie poczucie frustracji i przekonanie, że pomoc dla Romów jest nadużyciem, nie rodzi relacji wzajemności, dary nie są uznawane za dary, ich dystrybucja zdaniem rozmówcy jeszcze bardziej deprecjonuje Romów wśród mieszkańców wsi:

Mówię, całościowo tej zmiany nie widzę, więcej, mam wrażenie, że ta pomoc, która jest udzielana... bardziej szkodzi niż pomaga. To znaczy pomoc jest udzielana zazwyczaj materialnie dla tych uczniów i rodzice się, myślę, nauczyli tak, że im się pomoc należy, natomiast zupełnie tego nie doceniają. My piszemy projekty, dzieci dostają w szkole i ubrania, i książki, no i tam, co trzeba, natomiast... jakąs tam pomoc socjalną, natomiast do szkoły np. nie chodzą albo książek nie przynoszą i mają to gdzieś, żeby przestrzegać tego, co obowiązuje w szkole (wyw. 13).

Napięcie pogłębia się w sytuacji, gdy Romowie dość zdecydowanie domagają się w ich opinii należącej się pomocy materialnej. Szczególnie charakterystycznym zjawiskiem jest zmiana, a właściwie pojawienie się wśród Romów sposobu argumentowania odwołującego się do obowiązku pomagania Romom, który wskazywany jest przez wszystkich przedstawicieli administracji i pomocy społecznej:

Oni teraz to już tak powiedzmy nauczyli się pewnej retoryki... ta ich retoryka wynika z tego, że są pewne uwarunkowania prawne. Oni bez przerwy mówią, że oni są mniejszością, oni są pokrzywdzeni, oni pracy nie mają, im się należy. Należy się im utrzymanie od gminy, rządu itd. (wyw. 17).

Przywołuje się argumenty o psuciu Romów przez różne formy darów, w istocie przyczyniające się do ich dalszej marginalizacji, wyłączenia poza nawias relacji społecznych we wsi i niszczenia rudymentarnych form wymiany (handel prostymi narzędziami potrzebnymi w gospodarstwie), w które niegdyś zaangażowani byli miejscowi Romowie.

\section{KONKLUZJE}

W klasycznym dla antropologii ekonomicznej dziele Marshalla Sahlinsa Stone Age Economics wśród różnych rodzajów wzajemności występujących w relacjach społecznych czytamy o tzw. „wzajemności negatywnej”, w ramach której jedna ze stron stara się uzyskać coś za nic (Sahlins 1972: 192). Taki rodzaj pseudowymiany pojawia się w grach hazardowych, niektórych formach wrogich przejęć firm, grze giełdowej. Po, z konieczności ograniczonej, analizie lokalnych „,praktyk integracyjnych” można twierdzić, że w analizowanej przestrzeni społecznej stanowią one, w ostatecznym rozrachunku dość kosztowną, próbę nawiązania obustronnej wzajemności negatywnej. Oczywiście wiele obserwacji antropologicznych wskazuje, że w różnych systemach wymiany darów ludzie rzadko dają lub otrzymują rzeczy, 
które naprawdę są im potrzebne lub których jeszcze nie mają. W wymianie darów, w przeciwieństwie do działań w zakresie gospodarki towarowej, zazwyczaj bardziej chodzi o działanie symboliczne niż zaspokajanie obiektywnych potrzeb czy po prostu chęć posiadania jakiejś rzeczy (Wilk, Cliggett 2011: 188-189). Wymiana darów jest raczej znakiem wzajemnego uznania. W świetle przedstawionych wyników można powiedzieć, że Romowie w badanych społecznościach nie traktują ,praktyk integracyjnych” jako znaku społecznego uznania ze strony społeczeństwa większościowego. Także badani przedstawiciele społeczeństwa większościowego, „dając” swoje działania w sposób bezpośredni (realizatorzy szkoleń) lub pośredni (sąsiedzi), nie starają się wyrazić uznania kulturowej podmiotowości Romów, dostrzegając jednak w zachowaniu społeczności romskich brak wzajemności, co zgodnie z koncepcja M. Maussa prowadzi do moralnego poniżenia.

W świadomości badanych Romów nie może być pomocą to, co im się subiektywnie należy. Z ich perspektywy oferowane im w trakcie szkoleń kompetencje stanowią rzeczy zbędne, choć wymagające sporego wysiłku, który można zamienić w cenioną przez nie-Romów wartość. Niejasność całego procesu „integrowania” opartego na społecznej taktyce inicjowania wymiany wartości sprawia, że traktują go jak kolejne uaktualnienie tradycyjnych relacji „klienckich”. W ten sposób są w stanie przejąć od organizatorów „,praktyk integracyjnych" jedynie marginalny fragment całości świadczenia, które społeczeństwo większościowe przeznacza na zbudowanie wzajemnych relacji.

Jednocześnie najbardziej wyrazistym procesem zachodzącym pod wpływem obserwacji „praktyk integracyjnych” w umysłach środowisk nieromskich, zwłaszcza osób niezaangażowanych bezpośrednio w projekty, jest rozróżnienie na pomaganie Romom i korzystanie przez Romów z projektów. Programów i funduszy skierowanych do Romów nie traktuje się w kategoriach pomagania, ale darów powodujących dalszą deprecjację tej społeczności. W kontekście antropologii ekonomicznej przywołuje to refleksję o darach w typie agonistycznym, wśród których tradycyjnym prototypem jest obserwowana niegdyś w niektórych plemionach Indian północnoamerykańskich instytucja potlaczu (Wilk, Cliggett 2011). Mamy do czynienia z profesjonalizacją pomocy, która cały „proces integrowania” pozwala opisać słownictwem technicznym, niemal całkowicie pozbawiając go typowego dla relacji pomagania wymiaru etycznego.

Tworzona przez „praktyki integracyjne” sytuacja społeczna powoduje, że Romowie, starając się zdyskontować korzyści ze swojej sytuacji ekonomicznej, posługują się powszechnie zrozumiałymi kategoriami większościowego dyskursu, w których ich los jest przedstawiany. W tej chwili są to: marginalizacja, rasizm, prawa mniejszości. Dzięki temu ich sytuacja jest zamieniana w towar, nabiera wartości, jest godna alokowania funduszy (por. Comaroff, Comaroff 2011: 35). Społeczny dystans odczuwany przez Romów w stosunku do społeczeństwa większościowego, którego nośnikiem jest romanipen, paradoksalnie znów staje się narzędziem adaptacji, źródłem wartości i wzmocnienia pozycji społecznej w relacjach z nieromskim otoczeniem. Tożsamość i kultura romska są uważane za własność romskich liderów, którzy zarządzają nimi zarówno na poziomie europejskim, jak i lokalnym.

Projekt zostat sfinansowany ze środków Narodowego Centrum Nauki przyznanych na podstawie decyzji numer DEC-2011/01/D/HS5/01560. 


\section{BIBLIOGRAFIA}

Bartosz, Adam. 1978. Niektóre elementy tradycyjnej gospodarki Cyganów, „Etnografia Polska" 2: 131-142.

Biro, András. 2013. The price of Roma integration, w: W. Guy (red.), From victimhood to citizenship: the path of Roma integration, Budapest: Central European University Press, s. $11-40$.

Comaroff, John L. i Jean Comaroff. 2011. Etniczność sp. z o.o., Kraków: WUJ.

Davis, John. 1996. An anthropologist's view of exchange, „Social Anthropology” 3: 213-226.

Engebrigtsen, Ada I. 2007. Exploring Gypsiness, New York: Berghahn Books.

EU Framework for National Roma Integration Strategies up to 2020. 2011. European Commision: $\operatorname{COM(2011)~} 173$ final, http://ec.europa.eu/justice/policies/discrimination/docs/ com_2011_173_en.pdf [15.05.2013].

Gheorghe, Nicolae. 2013. Choices to be made and prices to be paid: potential roles and concequences in Roma activism and policy-making, w: Will Guy (red.), From victimhood to citizenship: the path of Roma integration, Budapest: Central European University Press, s. 41-100.

Godelier, Maurice. 2010. Zagadka daru, Kraków: WUJ.

Gudeman, Stephen. 2001. Postmodern Gifts, w: Stephen Cullenberg, Jack Amariglio i David F. Ruccio (red.), Postmodernism, Economics and Knowledge, Londyn: Routledge, s. 459-474.

Holmes, Douglas R. i George E. Marcus. 2009. Przeformułowanie etnografi: wyzwanie dla antropologii współczesności, w: Norman K. Denzin i Yvonna S. Lincoln (red.), Metody badań jakościowych, tom 2, Warszawa: PWN, s. 645-662.

Kowarska, Agnieszka J. 2005. Polska Roma. Tradycja i nowoczesność, Warszawa: DiG.

Leeson, Peter T. 2013. Gypsy law, „Public Choice” 155: 273-292.

Liegeois, Jean-Pierre. 2007. Roma in Europe, Strasburg: Council of Europe Publishing.

Marcus, George E. 1995. Ethnography in/of the World System: The Emergence of Multi-Sited Ethnography, „Annual review of anthropology” 24: 95-117.

Marushiakova, Elena i Vesselin Popov. 2005. The Roma - a Nation without a State? Historical Background and Contemporary Tendencies, w: Wojciech J. Burszta, Tomasz Kamusella i Sebastian Wojciechowski (red.), Nationalism Across the Globe, Tom I, Poznań: School of Humanities and Journalism, s. 433-456.

Mauss, Marcell. 2001. Socjologia i antropologia, Warszawa: Wydawnictwo KR.

Mirga, Andrzej. 1978. Me som Rom, tumen san gadźe, „Etnografia Polska” 2: 177-183.

Mirga, Andrzej. 1987. Kategoria ,romanipen” a granice etniczne Cyganów, „Kultura i Społeczeństwo" 1: 195-205.

Mróz, Lech. 1966. O problemie cygańskim, „Etnografia Polska” 10: 178-195.

Mróz, Lech. 1986. Wyróżnianie grupy własnej przez Cyganów w Polsce: swojskość, inność, obcość, „Etnografia Polska” 1: 139-162.

Nowicka, Ewa. 1995. Rom jako swój i jako obcy: zbiorowość Romów w świadomości społeczności wiejskiej, „Lud” 78: 357-375.

Nowicka, Ewa i Maciej Witkowski. 2013. Retoryka antydyskryminacyjna $w$ zmieniajacych się relacjach społeczeństwa większościowego z Romami. Przypadek Bergitka Roma we wsi karpackiej, „Studia Socjologiczne” 4: 143-164. 
Program Integracji Społecznej Romów na lata 2014-2020, Ministerstwo Administracji i Cyfryzacji.

Rostas, Iulius. 2013. Workshop debates, w: Will Guy (red.), From victimhood to citizenship: the path of Roma integration, Budapest: Central European University Press, s. 129-198.

Rostas, Iulius i Andrew Ryder. 2012. EU framework for National Roma Integration Strategies: insights into empowerment and inclusive policy, w: Joanna Richardson i Andrew Ryder (red.), Gypsies and Travellers: Empowerment and Inclusion in British Society, Chicago: Policy Press.

Sahlins, Marshall. 1972. Stone Age Economics, Chicago: Aldine.

Sedláček, Tomas. 2012. Ekonomia dobra i zła, Warszawa: Studia Emka.

Simhandl, Katrin. 2006. „Western Gypsies and Travellers” - „Eastern Roma”: the creation of political objects by the institutions of the European Union, „Nations and Nationalism” 1: $97-115$.

Stewart, Michael. 1997. The time of the Gypsies, Oxford: Westview Press.

Trubeta, Sevasti. 2013. Roma as Homines Educandi: a collective subject between educational provision, social control and humanism, w: Maja Miskovic (red.), Roma education in Europe, London: Routledge, s. 15-28.

Vermeersch, Peeter. 2006. The Romani movement, New York: Berghahn Books.

Wilk, Richard R. i Lisa Cliggett. 2011. Ekonomie i kultury, Kraków: WUJ.

Witkowski, Michał i Kazimiera Wódz. 2012. Some strategies of framing public discourse on Silesian region identity, w: Ewa Nowicka (red.), The Politics of Culture, Warszawa: Uniwersytet Warszawski, s. 168-188.

\author{
"HOW TO INTEGRATE THE ROMA: 10 PRACTICAL WAYS" \\ OR AN ANALYSIS OF THE CONTEMPORARY SITUATION OF THE ROMA \\ COMMUNITIES IN THE PERSPECTIVE OF GIFTS ANTHROPOLOGY
}

The article is based on the results of ethnographic fieldwork in the local Bergitka Roma settlements in Poland and their social environment conducted over the past three years Roma communities in Poland are currently a subject of intensive interactions with the "mainstream society", whose aim is socio-economic integration. Just as in the classic study of Marcel Mauss we also have to deal with an expected value exchange here. Mainstream society gives a gift in the form of funds for "integrative practices" and hopes that on the basis of reciprocity, Roma communities abandon those elements of their traditional way of life which can be problematic in a "democratic" and "integrated" society. The exchange of gifts is usually more of a symbolic action than satisfying "objective" needs. It is rather a sign of mutual recognition, a tactic to build social bonds. The text shows how the existing practice of integrating by gifts sometimes leads to moral humiliation.

Key words: Roma integration, Roma inclusion, gifts exchange, ethnic minorities in Poland, economic anthropology 